${ }^{55}$ Iowa Population Census, 1880. Although the census does have a column in which school attendance for individuals is marked, we have no way of knowing what school was attended. Consequently, some of the seven, especially the three of these who were only eighteen years old in July of 1880, may well have been attending district township schools. For instance, Burt Babcock, who was twenty-one years old in July of 1880-therefore, eighteen in July of 1877-is listed by the Press of December 27, 1877, as still attending Burr Oak Township district school number one.

${ }^{56}$ Computed from: Iowa Population Census, 1880.

${ }^{57}$ Garland, A Son of the Middle Border, p. 182.

\title{
AN 1885 EXCURSION FROM KEOSAUQUA TO STORM LAKE
}

George C. Duffield was born in Steubenville, Ohio on May 13, 1824. In 1835 he went to Illinois with his father's family in search of a permanent home. Their search eventually brought them to Iowa where in April of 1837 they made their homestead claim on Chequest Creek in Van Buren County, a couple of miles above the town of Keosauqua. The Duffield family composed the first family circle within the present limits of the State of Iowa, west of the great bend of the Des Moines River, save one, that of Samuel Clayton. In 1852, George Duffield erected a house on the adjoining section of his father's original claim and "Linwood Farm" was his home from that time until his death fifty-five years later in September 1908.

Duffield was a noted pioneer resident of Keosauqua and his delightful memories of early pioneer life in Iowa have been preserved in numerous articles written by him for the ANNALS. ${ }^{\circ}$ He was a delegate to the first Republican State Convention held in Iowa City in 1856, and was one of the

${ }^{\circ}$ Game in Jefferson County, Vol. 17, No. 6 (Oct. 1930), 415.

"Rifle \& Telephone," Vol. 7, No. 7 (Oct. 1930), 552.

"Coming into Iowa in 1837," Vol. 6, No. 1 (April 1903), 1.

"Frontier Church Going 1837," Vol. 6, No. 4 (Jan. 1904), 266;

"Frontier Mills," Vol. 6, No. 6, (July 1904), 42.

"Iowa Settler's Homestead," Vol. 6, No. 3 (Oct. 1903), 206; Recollections of Steamboating on the Des Moines, Vol. 4, No. 5 (April 1900), 364 . 


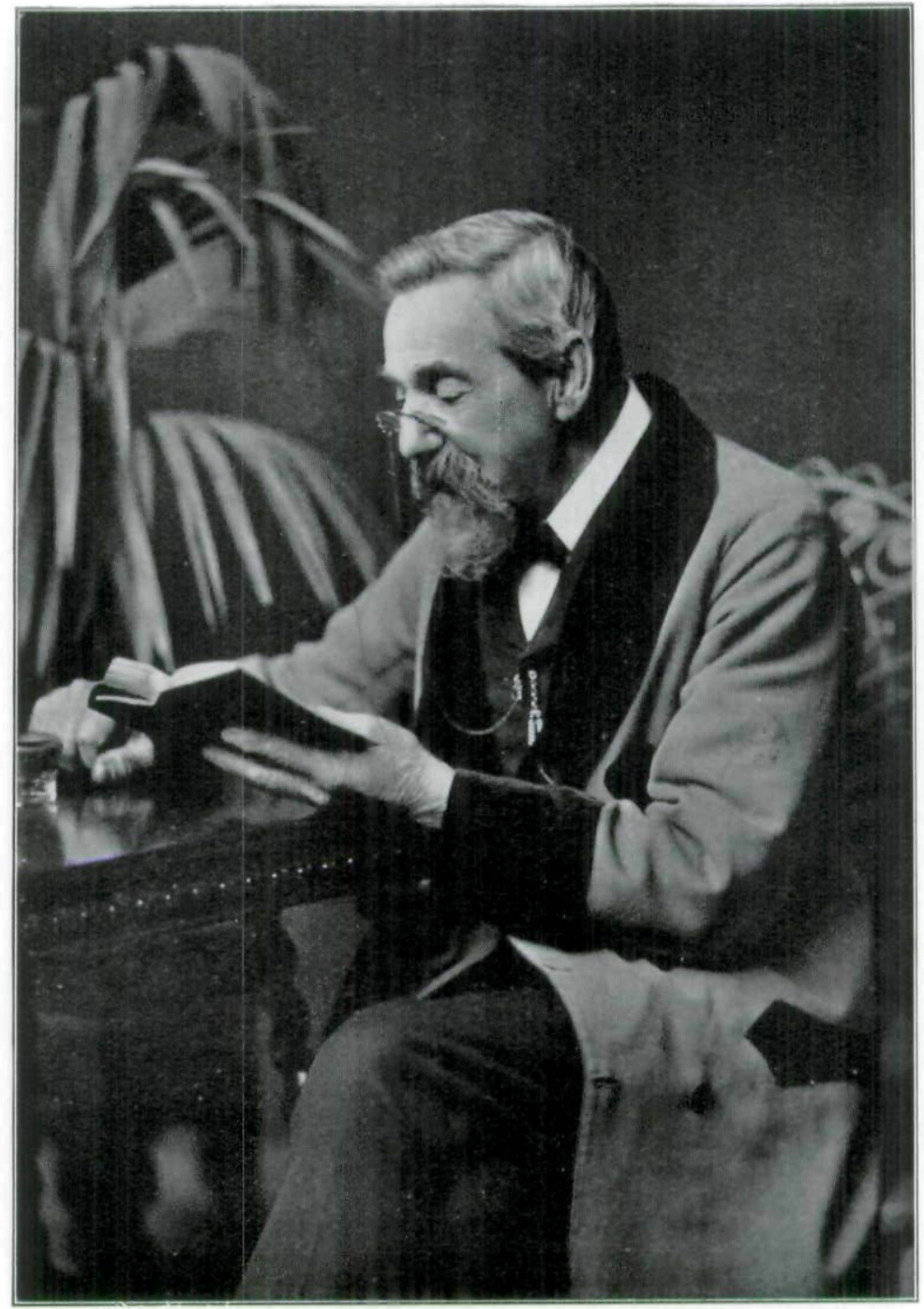

George C. Duffield 
founders of the Iowa State Agricultural Society which he served for twelve years as Director. As obituarian of the Van Buren County Pioneer Association, he compiled nearly one thousand sketches of the lives of men and women who lived in Van Buren County during or before 1846.

Because of the rugged nature of pioneer life and the grave necessity of procuring meat for the table, Duffield became an expert hunter. The following article is an interesting excerpt from one of his diaries, describing a combination hunting trip and excursion from Keosauqua to Storm Lake which he ventured on with a group of friends in 1855. Please note that the diary contained on the following pages is not the original but a copy of the original made by Mr. Duffield's son, with an attempt to reproduce it exactly as it was. We have also endeavored to print this document in its original form, nothing has been changed.

\section{COPY OF ORIGINAL BOOK BY GEO. C. DUFFIELD}

October 17th 1885 Jas Sheppard ${ }^{1}$ Joseph Barker² \& Geo. C. Duffield with J S Caruthers for cook left Keasauqua on a Trip to Lake Booyer ${ }^{3}$ to view the Country \& have a hunt We Camped the first night near Iowa Ville ${ }^{4}$ at or near was Caldwell [?]

18 We passed throught Iowa Ville Ashland ${ }^{5}$ Agency City ${ }^{6}$ Dehloniga $^{7}$ \& Kirkville \& Camped for the night

19 We passed through Oskaloosa Pella \& Munroe $^{8}$

20 Rising Sun to Ft Des Moines the Accomodations are poor \& we were Charged six Dollar for Keeping two Horses and the privilege of sleeping on the floor we furnishing our own beds. Hard rain

21 We lef D. \& travelled five Miles up Coon River $^{9}$ \& Camped where we built a good fire and dried our clothes. Cleaned our guns \& took a good rest-This is a bright nice day after the hard rain of yesterday

s. "Yor

"Youthtime in Frontier Iowa," Vol. 7, No. 5 (April 1906), 347; Reference to pioneer reminiscences of, Vol. 7, No. 6 (July 1906), 460, 461.

The ANNALS also published another very interesting Duffield Diary, "Driving Cattle From Texas To Iowa, 1866," Vol. 14, No. 4, April, 1924, pp. 243-262. 
22 We travelled 18 Miles. This has been a Snowy bad day We Camped in a bad place. with little wood \& fire and Snow in our tent all night

23 Moved two Miles to the Des Moines River and then took another rest \& dry up as we have an abundance of wood We are now beyond the settlement Except an accasssonal trapper. Beaver \& otter appear to be very plenty here,

24 We Moved across to Coon River to what is Called Buffalo Grove where we Camped for the night

25 We travelled up Coon Making our own road to what is called Hardins Grove We Experienced some trouble in Crossing some of the deceptive Marshes \& had to unload some of our Traps to get through the Marshy sloughs

26 We travelled about 8 Miles to Coon \& stopped to have a hunt I shot at a Deer \& broke its leg \& we had an Exciting Chase and caught it. Game is plenty but we are not Trying to Kill it believing we can load our wagon when we desire so to do

27 Travelled up Coon to Butricks Grove. I shot a fine Wolf to day.

28 Spent the day at this (Butricks Grove)

29 From Butricks by Lake Creek to Camp Creek. ${ }^{10}$ Here is the Most Beaver \& otter sign I have see on our Trip There is Dam on Coon \& other streams that resemble Mill dams \& the roar of the water over Them can be heard for Miles on a Calm night. In Many places the Groves of Ash \& Elm are almost destroyed by the Beaver, Trees from two feet in diam to small saplings being cut down by the Beaver for the purpose of Making their dams

30 This day we have accomplished the object for which we started-that is to see the Much talked of Wall Lake or Lake Booyer, \& returned to our Camp

Noon 1st Took a hunt \& Killed a very fine Deer.

2nd We Started this Morning to take a good view of the Lake and find it a very great wonder to us. It is a beautiful Sheet of water composd of or covering several sections of land \& the wonder of the Lake is the wall that surrounds South Side of it This wall is as complete as the 
Most skilled workman can make it. How it was formed is beyond My Comprehension. We saw a drove of Elk but did not get a Shot. We Camped in the Prairie without fire

3 We travelled due North \& Camped on the head waters of Coon River This is a delightfull contry but not likely to be settled for Many years as there is neither fuel nor fencing in reach. We saw 7 Elk \& the trail of large herds

4 Remained here to day and Killed two deer J Caruthers \& I had the Most Exciting race after a wounded deer I Ever had

5 Moved Down the River five Miles \& Camped

6 Killed two deer to day Lovely weather Grass dry \& many Prairie fire burning

7 Killed a very large Buck

8 We Concluded to go to Lake Booyer but started a Herd of Elk \& chased them all day We got one of them down but he got away after a chase of Several Miles.

We concluded to try to find Storm Lake which we believed to be in this vicinity \& turned our course north \& travelled by the No. Star until about Midnight when we camped for the night

9 We started on our journey \& travelled up a gradual assent until about 1 P.M. when to our astonish the beautiful lake lay in full view before us. I think It was the handsomest sight I Ever beheld as it Lay there surrounded by the boundless Prairie with no habitation in sight The wild Elk Deer \& Buffalo have the undistauted right to all this vast country \& likely will have for many years After a long view we turned our course for the head of Coon river where we could find some timber \& do some cooking. We reached a grove Called Deer Duffs Grove, in the Evening

10 We feel that we have Now accomplished all we Expected When we left our Homes and we packed up and turned our faces homeward We Killed two Deer and had to go back for them 8 Miles for them, Camped Near an Old Trappers Named Frances Ayres,

11 Travelled Down Coon 13 Miles 
12 Travelled 5 Miles through a hard rain \& Camped in big Woods We have had a hard day-got Stalled \& had to unload near a trappers Hut Mr Williamson was his name

13 Moved 3 Miles to lower End of big woods and Spent the day smoking our venison

14 Travelled twenty Miles down Coon River to Buttricks Grove This is a lovely Country \& will make grand homes for Emigrant's by \& buy.

15 Next day to a Creek with good timber where we Camped in a heavy rain \& got Every thing very wet Hard rain all night \& Creek bank full but we have Camped on the right side \& can go on

16 Travelled 20 Miles down Coon passed through Adel \& Camped in River bottom

17 During the night we were awake by the sudden breaking of ridge pole of our tent. and found it had been broken by the weight of Snow that had fallen on it. This Morning there is 8 inches of Snow on ground \& it looks as if there is trouble for us before we reach home We travelled 18 Miles \& it was a hard day on our Horses We Camped on North three Rivers All tired and hungry.

18 Travelled through Green Bush ${ }^{11}$ \& Indianola. Crossed Middle River \& Camped on S. River We have a hard day on ourselfes \& teems and a hard time scraping snow off for a camping place. (This is what we call Camping on the Corner of $\mathrm{Me}$ as the owner of the Clam called it when $\mathrm{He}$ gave us the privilege of camping there) Our Bed Clothes Caught fire in the night and were badly damaged

19 Passed through Sandy Hill. ${ }^{12}$ Pleasant Ville \& Camped I bought a pair of Boots to day. I was glad to get them as My feet were Exposed to the snow.

$20 \mathrm{Knoxville} \mathrm{Etica}^{13}$ \& Crossed two Cedars \& Camped on Bluff near Albany ${ }^{14}$

21 Travelled 12 Miles \& Camped We are reaching the settlement \& begin to think we are in the land of the living

22 We reached Stringtown ${ }^{15}$ and put up at the Tavern the first time we have been in a House since we left the famous Hotel Des Moines, 
$23 \mathrm{~J}$ Caruthers Came from the stable \& reported Mr. Sheppards Horse Frank dead We went to stable \& found it too true \& we were there with but one Horse. We concluded it was not healthy for Horses to stand in a stable as it was the first night on the trip. We hired a horse and reached our Homes at dusk well tired but well pleased with our trip. We killed all the Deer we could hand \& could have killed Many More. My Share of the Hides brought Me $28 \frac{00}{100}$ Dollars.

24 I Killed a Deer \& Stood in My own door here in Van Buren County then washed dressed \& took a good rest. Thus Ends one of the best Hunts I have had \& long will I remember the Party Jas Sheppard Joseph Barker J S Caruthers \& Geo. C. Duffield.

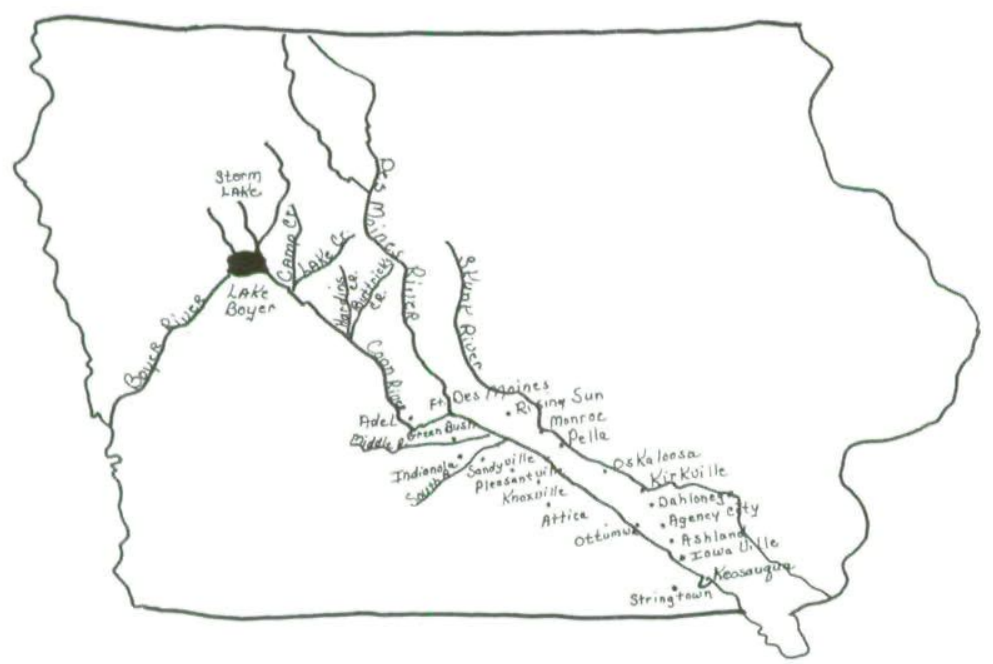

Map showing the route taken by George C. Duffield and his companions on their trip from Keosauqua to Storm Lake.

\section{NOTES}

${ }^{1}$ Jas Sheppard or James Shepherd was a pioneer journalist of Keosauqua. In 1844 he came to Keosauqua and took charge of The Iowa Democrat. Tacitus Hussey, "The Flood of 1851," ANNALS, Vol. 5, No. 
6 (July 1902), pp. 416-418. Shepherd was also the proprietor of the "Keosauqua House" and served at one time as Justice of the Peace for the town. C. C. Nourse, "Fifty Years at Iowa Bar," ANNALS, Vol. 8, No. 7 (Oct. 1908), p. 485.

${ }^{2}$ Joseph Barker was a pioneer settler of Keosauqua. In the History Of Van Buren County a Joseph Barker is mentioned as being a Saddle and Harness Maker in the Year 1846. History of Van Buren County, Iowa, 1878 , p. 468.

${ }^{3}$ Lake Boyer or Wall Lake was situated in townships 86 and 87 of range 36 in the southern portion of Sac County. It was probably referred to as Lake Boyer because of the Boyer River which empties into it. "This body of water covered an area of about three square miles and did not exceed a depth of 12 feet. Originally, a part of the shores of this lake were bordered by earth works, or an embankment of earth and boulders, in some places the latter having the appearance of a wall laid up by the hand of men, and hence the name Wall Lake." Wm. H. Hart, 1914 History of Sac County Iowa, Chapter I, pp. 25-26. Today Wall Lake is a part of the Black Hawk Lake area.

${ }^{4}$ Iowa Ville was a village on the west side of section 7, Village Township, and the north side of the Des Moines River, about one mile N.W. of the present village of Selma. At one time in the 1860's it was prosperous, having some 200 inhabitants. David C. Mott, "Abandoned Towns, Villages and Post Offices of Iowa," ANNALS, Vol. 18, No. 2 (Oct. 1931), p. 129.

${ }^{5}$ Ashland was located 3 miles North of the present town of Eldon. It was a town of importance on the stage line at one time, having several stores, an Academy and a few hundred inhabitants. Ibid., p. 132.

${ }^{6}$ Agency City is today Agency.

${ }^{7}$ Dahlonega was located 5 miles N.E. of Ottumwa and was also an important town in its day. At one time the now abandoned town had over 300 inhabitants and aspired to be a county seat. Op. cit., Mott, p. 132.

${ }^{8}$ Monroe

${ }^{9}$ Racoon River

${ }^{10}$ Lake Creek and Camp Creek are shown on the map on page 873. On the Williams and Barnes 1855 Map of Iowa these two creeks are shown to be located in the southwestern portion of the then designated Calhoun County.

${ }^{11}$ Green Bush was a village located about one mile N.W. of the present town of Spring Hill. Op. cit., Mott, p. 134.

${ }^{12}$ Duffield probably meant Sandyville. Sandyville is located 5 miles east of the present town of Ackworth and at one time was prosperous. Today only a few scattered buildings remain. Ibid., p. 136.

${ }^{13}$ Attica

${ }^{14}$ Albany was in N. W. Davis County.

${ }^{15}$ Stringtown was located in Davis County and was situated about one mile south of the present town of Troy. The post office at Stringtown was called Fox from 1842 to 1853 . It was platted as Dover in 1848 but was called Harpersville sometimes and later Stringtown. $O p$. cit., Mott, Vol. 17, No. 7 (Jan. 1931), p. 515. 
Copyright of Annals of Iowa is the property of State of Iowa, by \& through the State Historical Society of Iowa and its content may not be copied or emailed to multiple sites or posted to a listserv without the copyright holder's express written permission. However, users may print, download, or email articles for individual use. 